\title{
HEPATICS OF THE CAUCASIAN STATE NATURE RESERVE (WESTERN CAUCASUS, RUSSIA)
}

\section{ПЕЧЕНОЧНИКИ КАВКАЗСКОГО ГОСУДАРСТВЕННОГО БИОСФЕРНОГО ЗАПОВЕДНИКА (ЗАПАДНЫЙ КАВКАЗ, РОССИЯ)}

\author{
N.A. KONSTANTINOVA ${ }^{1}$, T.V. AKATOVA ${ }^{2} \&$ A.N.SAVCHENKO ${ }^{1}$ \\ Н.А. КОНСТАНТИНОВА ${ }^{1}$, Т.В. АКАТОВА ${ }^{2}$, А.Н. САВЧЕНКО ${ }^{1}$
}

Abstract

The annotated list of hepatics for the Caucasian State Nature Reserve (CSNR), one of the largest reserves in European Russia, records 126 species based on approximately 700 specimens collected by the authors. 12 species (Calypogeia sphagnicola, Cephalozia ambigua, Cephaloziella aspericaulis, C.varians, Jungermannia pumila, Lunularia cruciata, Mannia androgyna, Marsupella sparsifolia, Pallavicinia lyellii, Peltolepis quadrata, Sauteria alpina, Scapania brevicaulis) are new records for the Russian part of the Caucasus, 74 are new for the Republic of Adygeya. New localities for eight red-listed European species and five that are red-listed in the Krasnodarskyi Territory also are documented, indicating significant conservation value of the resereve. The greater richness of the flora of the Caucasian Reserve by comparison to that of Teberdinsky Reserve in Northern Caucasus is discussed.

Резюме

Приводится аннотированный список печеночников Кавказского государственного биосферного заповедника, одного из крупнейших заповедников европейской части России, насчитывающий 126 видов. Двенадцать видов (Calypogeia sphagnicola, Cephalozia ambigua, Cephaloziella aspericaulis, C.varians, Jungermannia pumila, Lunularia cruciata, Mannia androgyna, Marsupella sparsifolia, Pallavicinia lyellii, Peltolepis quadrata, Sauteria alpina, Scapania brevicaulis) указываются впервые для российской части Кавказа, 74 вида - для республики Адыгея. Выявлены новые местонахождения 8 видов, внесенных в Европейский список редких и исчезающих видов, и 5 включенных в Красную книгу Краснодарского Края, что определяют значительную природоохранную ценность территории. Проведено сравнение флоры печеночников Кавказского и Тебердинского заповедников.

KEYWORDS: Hepatics, flora, rare species, Caucasus, Caucasian Nature Reserve

INTRODUCTION

The Caucasian State Nature Reserve (CSNR) is situated in the western part of the Great Caucasus and includes both northern and southern macroslopes of the Great Caucasian Range, some parts of the Bokovoy and Peredovoy Mountain Ridges particularly upper coarses of the Belaya, Laba, Shakhe, Sochi and Mzymta Rivers, and also the Khosta's Taxus and Buxus Forest in the coastal area of the Black Sea (Fig. 1). The main part of the reserve occupies a vast area of 280,034 hectars in the mountains and a much smaller one

${ }^{1}$ - Polar-Alpine Botanical Garden, Kola Sci. Center of Russian academy of Scienses, Kirovsk-6, Murmansk Province 184256 Russia - Россия 184256, Кировск-6 Мурманской области, Полярно-альпийский ботанический сад-институт КНЦ РАН; e-mail: nadya50@list.ru

2 - Maikop Branch of Caucasian Nature Biosphere Reserve, Sovetskaya str., 187, Maikop, Adygea Republic, 385000 Russia - Россия 385000 Республика Адыгея, Майкоп, Советская 187, Кавказский государственный природный биосферный заповедник, Майкопское отделение; e-mail: hookeria@mail.ru 
(301.3 hectare) near Khosta City. Geopolitically, the reserve consists of parts of the Republic of Adygeya, the Karachaevo-Cherkessiya, and the Krasnodarskiy Territory. The largest part lies in the Republic of Adygeya (Fig. 1, collecting sites $2,3,4)$, while the northeastern part is in the Karachaevo-Cherkesskaya Republic (Fig. 1, site 5) and the coastal area and south slopes are situated in the Krasnodarskiy Territory (Fig. 1, sites 1 and 6). The mountainous part of the reserve is located between $43^{\circ} 30^{\prime}$ and $44^{\circ} 05^{\prime} \mathrm{N}$, and $39^{\circ} 45^{\prime}$ and $40^{\circ} 50^{\prime} \mathrm{E}$, and ranges from 400 to $3360 \mathrm{~m}$ elevation, while the coastal part lies on the spur of

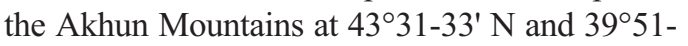
$53^{\prime} \mathrm{E}$, and ranges from 40 to $520 \mathrm{~m}$ elevation.

\section{CLIMATE AND VEGETATION}

The territory of the CSNR lies on the border between temperate and subtropical climate regions and belongs to the forest-continental, Chernomorskaya and mountain subdistricts of the North Caucasian mountain climate district (Alisov, 1956). The climate of the coastal territory (Khosta's Taxus and Buxus Forest, Fig. 1:6) is wet temperate, but close to wet subtropical, with a mean annual temperature between 13.8 and $14.5^{\circ} \mathrm{C}$, and annual precipitation of $1400 \mathrm{~mm}$. The middle mountain zone of the southern macroslope is characterized by a mean annual temperature of $9.8^{\circ} \mathrm{C}$ and annual precipitation of $1676 \mathrm{~mm}$, whereas on the northern macroslope the annual temperature varies from +1 to $+6^{\circ} \mathrm{C}$, and annual precipitation varies from 700 to $1200 \mathrm{~mm}$. The climate of the upper mountain zones is cold alpine with a mean annual temperature of $+3.5^{\circ} \mathrm{C}$, and a high level of annual precipitation that ranges from 1300 to 3250 mm (Chubukov, 1966).

The situation of the CSNR at the border of two biogeographical provinces, North and West Caucasian as well as a huge area and a wide variety of natural conditions account for the remarkable floristic and vegetational diversity. Approximately $62 \%$ of the reserve is covered by forests. These include broad-leaved (beech and hornbeam-oak) forests, mixed, and coniferous (mostly fir) forests with evergreen kolkhid understory. On the southern macroslope, some areas are occupied by forests with Castanea sativa Mill. and Buxus colchica Pojark. Timberline is formed by elfin birch or beech forests, maple "park" for- ests, pine forests and subalpne meadows. The upper parts of mountains (above $1700 \mathrm{~m}$ elev.) are occupied by subalpine, alpine and subnival vegetation. A more detailed description of climate, relief and vegetation is presented in Akatova (2002) and Ignatov et al. (2002).

\section{EXPLORATION OF THE HEPATIC FLORA OF THE CSNR}

A study that focuses on the hepatics of the CSNR has never before been undertaken. Hepatics were collected in the course of an inventory of the flora of the Reserve in 1935 by Vasilyeva, but her data were not published. The herbarium of the CSNR includes a number of Vasilyeva's collections that were partially revised during the present study. The only territory of this huge Reserve where the hepatic flora was documented previously is Khosta's Taxus and Buxus Forest. In 2002, Akatova, Ignatov and Ignatova collected bryophytes, including hepatics, in this area. As result, 28 species of liverworts were recorded previously for this territory (Ignatov et al., 2002).

In the course of this study, a total of ca. 700 specimens have been identified and a number of specimens gathered earlier by Vasiljeva (V.) and T. Akatova (T.A.) also have been examined.

\section{ANNOTATED LIST OF SPECIES}

The names follows Konstantinova \& Bakalin et al. (2009). After them, the information is provided on the presence of reproductive structures, usung the following abbrviations: and. - androecia; gyn. - gynoecia, per. - perianthia or pseudoperianthia, spor. - sporogonia, gem. - gemmae. Then the collecting localities (1-6, cf. Fig. 1) are given, followed by a characterization of the habitats. Elevation range is given in parenthesis for rather widespread species, while for rare ones the labels are cited in full, including coordinates and elevation for each place and specimen information (either collector numbers of Konstantinova and Savchenko, started with $\mathrm{K}$, or date and name of other collectors). For more common species, specimens are not cited, but their frequency are given as follow: sporadic (5-10 collecting sites), frequent (11-15 localities) and common (more than 15 localities). Associated species of hepatics are cited as well. New records for the Caucasus are marked by two asterisks and by one asterisk for the Adygeya Republic. Specimens are deposited in KPABG. 


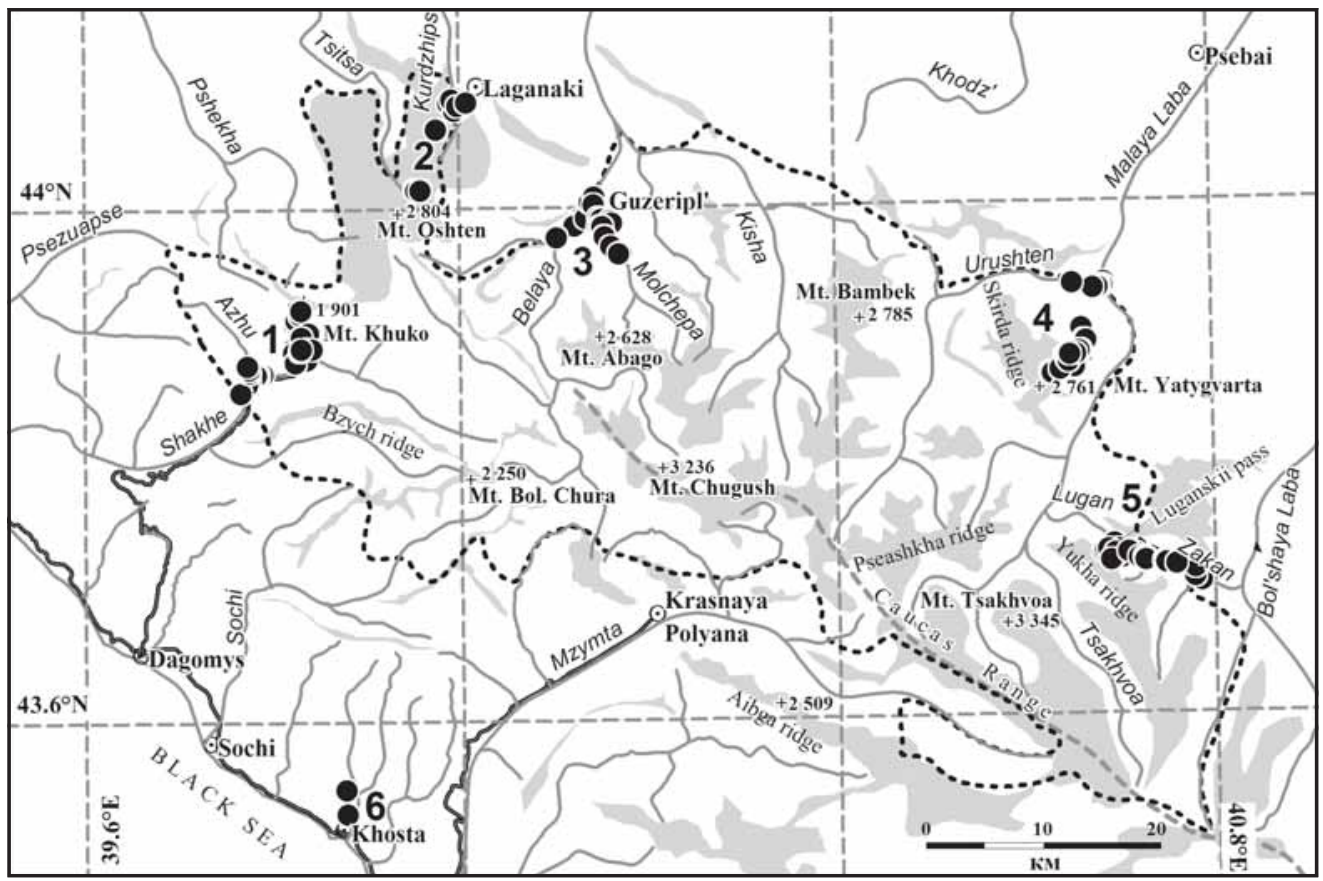

Fig. 1. Collecting localities: 1 - Upper Shakhe River, western spurs of Huko Ridge in the vicinity of BabukAul, 230-1560 m alt., 23.IX-3.X.2008; 2 - Lagonaki Plateau, including the Upper Kurdzhips River and the bottom of Oshten Mountain, 1490-2200 m alt., 9.X-13.X.2007; 3 - Vicinity of Guseripl Town, including the valley of the Belaya River and its tributaries, the Molchepa and Filimonovskiy Streams, 650-1000 m alt., 15.X-21.X.2007; 4 - Malaya Laba River Basin, including the vicinity of Chernorech'e village and the Urushten River valley and the slopes of Snegovalka Ridge, including Armovka Mountain, 800-2500 m alt., 16.IX27.IX.2009; 5 - northeastern slopes of Yukha Ridge, including the source of the Zakan River and Luganskiy Pass, 1300-2700 m alt., 13.IX-18.IX.2008; 6 - Valley of the Khosta River, including Khosta's Taxus and Buxus forest and the "Chertovy Vorota" area, 50-250 m alt., 27.X-29.X.2007.

*Anastrophyllum michauxii (F.Weber) H. Buch (per., gem.) - 2: left tributary of Kurdzhips River, in firdominated forest, on rotten $\log , 44^{\circ} 5^{\prime} 6^{\prime}$ ' $\mathrm{N}$ 39 59'34' E, 1552 m (K433-3-07). An earlier report of this species from Psenodakh Lake by L.Vasiljeva (3.IX.1935, V.) is based on a misidentification of Scapania aequiloba.

Aneura pinguis (L.) Dumort. (per., and.) - 1, 2, 3, 4, 5, $6(50-2400 \mathrm{~m})$ : on rotten logs along streams, and in moist coniferous and mixed deciduous coniferous forests; among bryophytes on side of hillocks in alpine meadow; and on peat in mires (Luganskiy Pass). In pure mats or mixed with mosses and hepatics. Common.

*Anthelia juratzkana (Limpr.) Trevis. (per., and., spor.) $-4,5(2200-2500 \mathrm{~m})$ : in moist crevices on wet cliffs; among debris in grass-undershrub-lichen tundra on steep slopes; in snowbed communities around pools and lakes in cirques; among boulders in rock fields; and at the bottom of cliffs. Sporadic in subalpine and alpine zones. In pure mats or mixed with
Pseudolophozia sudetica, Scapania subalpina, Sphenolobus minutus, Lophoziopsis excisa, Cephaloziella divaricata, Plagiochila porelloides etc.

Apometzgeria pubescens (Schrank) Kuwah. - 2, 3, 4 $(650-1700 \mathrm{~m})$ : on rocks and cliffs in broad-leaved forests or along the banks of streams. Sporadic. Often in extensive pure mats with an admixture of Jubula hutchinsiae ssp. javanica, Metzgeria conjugata, Plagiochila porelloides.

* Asterella lindenbergiana (Corda ex Nees) Arnell (and., spor.) - 2: north facing slope of Abadzesh Ridge, on ledge of doline (deep hole-like karst depression on gentle slope), $44^{\circ} 2^{\prime} 10^{\prime \prime} \mathrm{N}-40^{\circ} 0^{\prime} 38^{\prime \prime} \mathrm{E}$, 1949 m (K437-1-07). 4: northeast spur of Armovka Mountain, depression between calcareous cliffs on north facing steep slope of cirque, under rocks on thin soil, 4352' $6^{\prime \prime} \mathrm{N}-40^{\circ} 38^{\prime} 21^{\prime \prime} \mathrm{E}, 2452 \mathrm{~m}$ (K1461-09); cirque of Armovka Mountain, north-south oriented crack, at the bottom of cliffs, on soil 4352'27"N - 40³8'52"E, 2195 m (K157-1-09).

*Athalamia hyalina (Sommerf.) S. Hatt. (gyn., and., 
dioicous) - 2: left bank of Kurdzhips River, in crevices at the base of cliffs, $44^{\circ} 4^{\prime} 59^{\prime \prime} \mathrm{N}-39^{\circ} 59^{\prime} 59^{\prime \prime} \mathrm{E}$, 1495 m (K430-1-07). 4: North-east spur of Armovka Mountain, depression between calcareous cliffs on north facing steep slope of cirque, under rocks on thin soil, $43^{\circ} 52^{\prime} 6^{\prime \prime} \mathrm{N}-40^{\circ} 38^{\prime} 21^{\prime \prime} \mathrm{E}, 2452 \mathrm{~m}$ (K146-2,3-09).

*Barbilophozia barbata (Schmidel ex Schreb.) Loeske -2 : north facing cliffs near Asishskiy Pass, in grass stand on dead lichens at the base of cliffs, $44^{\circ} 5^{\prime} 6^{\prime}$ ' $\mathrm{N}-40^{\circ} 0^{\prime} 47^{\prime}$ 'E, $1719 \mathrm{~m}$ (K443-3-07). 4: on rock in broad-leaved forest, $43^{\circ} 54^{\prime} 1^{\prime \prime} \mathrm{N}-40^{\circ} 39^{\prime} 43^{\prime \prime} \mathrm{E}, 1751$ m (K162-4a-09).

B. hatcheri (A. Evans) Loeske (gem.). - 2, 4, 5 (1700 $-2400 \mathrm{~m}$.): in subalpine and alpine zones, between rocks and on rocks in rock fields, on soil in undershrub-moss-lichen tundra, on hillocks among Sphagnum in boggy meadow and on the side of brooks. Sporadic. In pure mats or with Cephalozia pleniceps, Lophoziopsis longidens, Scapania irrigua, Pellia neesiana etc.

*B. lycopodioides (Wallr.) Loeske - 4: northeast spur of Armovka Mountain, light birch forest with Rhododendron caucasicum Pall. on north facing slope, among grasses, 4352'58"N - 40³9’39"E, $1993 \mathrm{~m}$, (K127-2-09), some plants among Obtusifolium obtusum and cirque on northern macroslope of Snegovalka Ridge, in Alchemilla- grass- moss meadow, among grasses, $43^{\circ} 51^{\prime} 55^{\prime \prime} \mathrm{N}-40^{\circ} 37^{\prime} 50^{\prime \prime} \mathrm{E}, 2453$ m (K141-2-09), with an admixture of Plagiochila porreloides. 5: north facing slope of Yukha Mountain, Rhododendron caucasicum - herb communi-

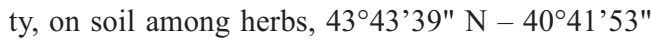
E, 2418 m (K320-3-08), with Lophozia wenzelii var. massularioides, Marsupella funckii and rock field in subalpine zone, on rocks shaded by herbs, 434'ㄹ' $8^{\prime \prime} \mathrm{N}-40^{\circ} 41^{\prime} 41^{\prime \prime}$ E, 2475 m (K331-2c-08).

*Bazzania tricrenata (Wahlenb.) Lindb. - 3: right bank of Molchepa River in the middle reach, on rotten $\log$ of Abies, partly in the river bed, 43.57' $49^{\prime \prime} \mathrm{N}-$ $40^{\circ} 10^{\prime} 12^{\prime \prime}$ 'E, $816 \mathrm{~m}$ (K480-2a-07), mixed with Scapania verrucosa, Plagiochilla porellodes.

B. trilobata (L.) Gray - 5: old beech forest, at bases of several trunks and quite recently fallen logs, $43^{\circ} 32^{\prime} 50^{\prime \prime} \mathrm{N}-39^{\circ} 52^{\prime} 30^{\prime \prime} \mathrm{E}, 250 \mathrm{~m}$ (Ignatov et al., 2002).

*Blasia pusilla L. (gem.) - 1: valley of Bushujka River, dry river bed, on silting rocks, $43^{\circ} 53^{\prime} 29^{\prime \prime} \mathrm{N}-$ 3950'14" E, 534 m (K398-2-08), mixed with Pellia endivifolia. 5: right bank of Zakan River, on side of road in mixed coniferous - broad-leaved forest (K304-08).

Blepharostoma trichophyllum (L.) Dumort. (per., and., spor.) - 1, 2, 3, 4, 5, 6 (350 - $2400 \mathrm{~m})$ : mostly on rotten logs in broad-leaved, coniferous and mixed forests, in alpine zone among bryophytes in tundra and over soil covered rocks on cliffs. Common. Usually mixed with hepatics and mosses.

Calypogeia azurea Stotler \& Crotz - 5: source of Zakan River, east facing slope, Rhododendron caucasicum stands, on steep banks along shallow stream, $43^{\circ} 43^{\prime} 15^{\prime \prime} \mathrm{N}-40^{\circ} 42^{\prime} 6^{\prime \prime}$ E, $2377 \mathrm{~m}$ (K343-1-08) and in Rhododendron caucasicum stands on bank of right tributary of Zakan River, $43^{\circ} 43^{\prime} 13^{\prime \prime} \mathrm{N}-40^{\circ} 43^{\prime} 12^{\prime \prime}$ E, 2144 m (K319-08), with Cephalozia pleniceps, Pellia neesiana.

C. fissa (L.) Raddi (per.) - $1(150-760 \mathrm{~m})$ : on soil and soil-covered rocks, among the roots of trees in fresh beech and chestnut-beech forests, along roads and trails, frequent. 6: on decaying logs mostly of Taxus baccata L., along roads and trails and banks of streams. Frequent.

C. muelleriana (Schiffn.) Müll. Frib. - 5: Luganskiy Pass, boggy meadow, on peat soil on bank of stream with Plectocolea obovata, Cephalozia bicuspidata, 43ํํ'45" N - 4041'47"E, 2411 m (K311-3-08) and on bare soil among grasses with Scapania undulata, Pellia neesiana (K314-2-08).

${ }^{* *}$ C. sphagnicola (Arnell \& J. Perss.) Warnst. \& Loeske - 5: Luganskiy Pass, boggy meadow, sedgegrass - Sphagnum bog, among mosses $43^{\circ} 43^{\prime} 45^{\prime \prime} \mathrm{N}$ - 4041'47"E, 2411 m (K312-1-08), with Scapania paludosa, Cephalozia bicuspidata, Pellia neesiana; source of Luganka River, herb- Sphagnum bog, on hillocks among Sphagnum, 4343'39" N 4041'13"E, 2492 m (K321-3-08), with Cephalozia pleniceps, Scapania irrigua, Barbilophozia hatcheri, Pellia neesiana.

*C. suecica (Arnell \& J. Perss.) Mull. Frib. - 2, 3, 4, $5(690-2000 \mathrm{~m})$ : on rotten logs in coniferous forests (Picea and Abies dominated) and in mixed broad-leaved -coniferous forests. Usually mixed with Lepidozia reptans, Cephalozia bicuspidata, Blepharostoma trichophyllum, Cephalozia lunulifolia, Riccardia palmata. Sporadic.

**Cephalozia ambigua C. Massal. (per.) - 5: Luganskiy Pass, boggy meadow, on hillock on bank of small

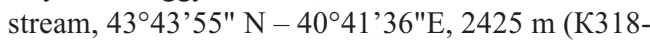
2a-08), with Lophozia wenzelii var. massularioides. ${ }^{*}$ C. bicuspidata (L.) Dumort. (per., and., spor.) - 2, 3, 4, $5(400-2400 \mathrm{~m})$ : on peat, soil and rocks covered by soil, on side of hillocks in boggy meadow and herb-sedge- Sphagnum bogs, on banks of small streams and pools, on rotten logs in fresh coniferous and broad-leaved-coniferous forests, on bare soil in Rhododendron caucasicum stands. Common. Usually mixed with hepatics Cephalozia lunulifolia, Tritomaria exsecta, Blepharostoma trichophyllum, Scapania irrigua, etc.

${ }^{*}$ C. catenulata (Huebener) Lindb. (per., and.) - 3, 6: 
(50-700 m): on rotten logs in Fagus - Abies forests in deep canyons. In pure mats or mixed with Blepharostoma trichophyllum, Calypogeia suecica, Crossogyna autumnalis, Nowellia curvifolia, Lophocolea heterophylla, Riccardia palmata, Tritomaria exsecta. Sporadic.

*C. lunulifolia (Dumort.) Dumort. (per., and., spor.) $2,3,4,5,6(50-2100 \mathrm{~m})$ : on wet rotten logs in coniferous and broad-leaved - coniferous forests, including old beech forests with Taxus baccata L. Frequent in appropriate sites. Usually mixed with Lepidozia reptans, Lophocolea heterophylla, Cephalozia bicuspidata, Blepharostoma trichophyllum, Calypogeia suecica, Riccardia palmata, Harpanthus scutatus, Crossogyna autumnalis etc.

${ }^{*}$ C. pleniceps (Austin) Lindb. - 2, 4, 5 (2000 - 2500 $\mathrm{m}$ ): on peat, soil on side of hillocks in boggy meadow, in Rhododendron caucasicum stands, in herblichen communities. In subalpine and alpine zones, sporadic. Usually mixed with Cephalozia bicuspidata, Blepharostoma trichophyllum, Leiocolea heterocolpos, Scapania irrigua, Solenostoma confertissimum, etc.

**Cephaloziella aspericaulis Jørg. - 4: northeast spur of Armovka Mountain, huge rocks in stand of Juniperus sp. in subalpine meadow, on ledge in the shade of Juniperus on dead mosses and among lichens, $43^{\circ} 52^{\prime} 25^{\prime \prime} \mathrm{N}-40^{\circ} 39^{\prime} 26^{\prime \prime} \mathrm{E}, 2252 \mathrm{~m}$. Pure mat with several plants of Barbilophozia hatcheri at the edge of mat (K143-1-09).

${ }^{*}$ C. divaricata $(\mathrm{Sm}$.) Schiffn. (per., and., dioicus) -2 : left bank of the Kurdzhips River, on trunk of Abies covered by mosses, $44^{\circ} 4^{\prime} 52^{\prime \prime} \mathrm{N}-40^{\circ} 00^{\prime} 01^{\prime \prime} \mathrm{E}, 1524$ m (K417-3в-07), with Cephaloziella rubella.

**var. asperifolia (Taylor) Macvicar - 4: right bank of Urushten River, broad-leaved forest (Fagus orientalis Lipsky dominated with ferns in the ground layer), on trunk of Fagus orientalis covered by moss-

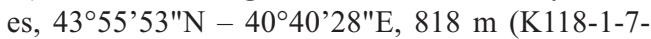
09), on hard wood or among hepatics: Riccardia palmata, Novellia curvifolia, Crossogyna autumnalis, Calypogeia suecica, Blepharostoma trichophyllum etc.

${ }^{* *}$ C. rubella (Nees) Warnst. (per., and., spor., paroicous) - 2: left bank of Kurdzhips River, on trunk of Abies covered by mosses, on lichens and mosses, $44^{\circ} 4^{\prime} 52^{\prime \prime} \mathrm{N}-40^{\circ} 00^{\prime} 01^{\prime \prime} \mathrm{E}, 1524 \mathrm{~m}$ (K417-3a-07), with Calypogeia suecica and Lophocolea heterophylla.

C. turneri (Hook.) Müll.Frib. (per., and.) - 1: southern spur of Khuko Mountain, along edge of trail to Cherkesskiy Pass, $43^{\circ} 54^{\prime} 2^{\prime \prime} \mathrm{N}-39^{\circ} 49^{\prime} 49^{\prime \prime}$ E, 754 m (K370-3,4-08), mixed with Diplophyllum albicans, Calypogeia fissa. 6: subvertical soil bank along the "Chertovy Vorota" trail (Ignatov at al., 2002).
${ }^{* *}$ C. varians (Gottsche) Steph. -5 : steep slope in the cirque of Yukha Mountain, under small boulders in grass-undershrub-lichen tundra, 43'35"N 4041’01"E, $2521 \mathrm{~m}$ (К330-1,2-08), mixed with Scapania brevicaulis, S. praetervisa, Sphenolobus minutus.

*Chiloscyphus pallescens (Ehrh. ex Hoffm.) Dumort. $-1,2,4,5(600-2450 \mathrm{~m})$ : on soil and herb detritus among grasses in moist depressions in subalpine meadow and bogs, on rocks and soil along streams, on rotten logs in very moist sites, at the base of cliffs. Sporadic. Usually in pure mats or with an admixture of Pellia spp., Scapnia spp. Jungermannia atrovirens, Pedinophyllum interruptum.

*Ch. polyanthos (L.) Corda (and.) - 1, 3, 4, 5 (700 $2500 \mathrm{~m}$ ): on rocks on banks of streams and in brookbeds, on soil and herb detritus in moist depressions in subalpine meadows and bogs. Sporadic. Usually in pure mats or with an admixture of Pellia endiviifolia, Scapnia spp.

Cololejeunea calcarea (Libert.) Schiffn. (per.) - 1: on wet shaded limestone cliffs along road on the left bank of the Shakhe River, 4351'59" N - 39 $49^{\circ}$ '31" E, $258 \mathrm{~m}$ (K422-2-08), 4351'49" N - 3946'23" E, $233 \mathrm{~m}$ (K423-2-08, K424-08), with an admixture of Pedinophyllum interruptum. 6: cliffs in the "Labirintovaya" canyon, $150 \mathrm{~m}$ (Ignatov at al., 2002).

${ }^{*}$ C. rossetiana (C. Mass.) Schiffn. -1 : spur of Khuko Mountain, on cliffs at the source of the Kholodnyi Creek, 435' $16^{\prime \prime} \mathrm{N}-39^{\circ} 49^{\prime} 50^{\prime \prime}$ E, 1552 m (K3831-08), with an admixture of Metzgeria conjugata, Radula lindenbergiana. 3: right bank of the Belaya River, on moist ledges of schist cliffs, 43 $59^{\prime} 27^{\prime \prime} \mathrm{N}$ - 407'44' E., 700 m (K464-8a-07), mixed with Pedinophyllum interruptum, Plagiochila porelloides. 6: on cliffs, concrete blocks of bridge, base of Fraxinus trunks (Ignatov et al., 2002).

*Conocephalum conicum (L.) Dumort. (jung spor.) $1,2,3,4,5,6(50-900 \mathrm{~m})$ : on moist cliffs, on soil at the bottom of cliffs, on banks of streams especially near waterfalls where it frequently covers several square meters, the most common hepatic in the forest zone, in the subalpine zone sporadically.

**C. salebrosum Szweyk., Buczk. \& Odrzyk. - 2, 3, $4,6(150-2150 \mathrm{~m})$ : on rocks and soil in moist forests, on banks of sources and streams in forest and subalpine zone. Frequent.

*Crossogyna autumnalis (DC.) Schljakov (per., and., spor.) - 1, 2, 3, 4, 5 (400 - $1550 \mathrm{~m}$.): on decaying Fagus and Abies logs, sometimes on bark at the base of trees in mixed broad-leaved-coniferous forests and in coniferous forests. Frequent. In pure mats or mixed with Blepharostoma trichophyllum, Cephalozia spp., Lepidozia reptans etc.

*Diplophyllum albicans (L.) Dumort. (per., gem.) - 
1, $3(430-754 \mathrm{~m})$ : on cliffs along the banks of rivers and streams, on rock in Rhododendron ponticum L. stands, on rocks and soil between roots in broad-leaved forests, sometimes on the side of trails. Sporadic. Mostly in pure mats

D. taxifolium (Wahlenb.) Dumort. - 5 (2400 - 2550 $\mathrm{m})$ : on cliffs in alpine meadow with Rhododendron caucasicum, in crevice under overhangs of grasses and Rhododendron, between and under rocks in rock fields, often in pure mats or mixed with Barbilophozia hatcheri, Gymnomitrion concinnatum, Cephalozia pleniceps etc. Sporadic.

Frullania bolanderi Austin. - 1: southern spurs of Khuko Mountain, near the trail to Cherkeskiy Pass, on Fagus orientalis in beech forest with Rhododen-

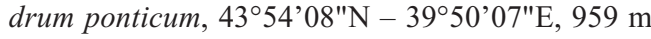
(K375-1-08). 4: left bank of Urushten River, beech forest, on bark of Fagus orientalis (ca $0.7 \mathrm{~m}$ diameter), at a height of ca. $1.5 \mathrm{~m}, 43^{\circ} 55^{\prime} 57^{\prime \prime} \mathrm{N}-$ 4040'53"E, $811 \mathrm{~m}$ (K110-2-09).

F. dilatata (L.) Dumort. (per., and., spor.) - 1, 2, 3, 4, 5, $6(50-900 \mathrm{~m})$ : on the bark of broad-leaved trees as well as on trunks of regrowth of Abies in broadleaved, mixed and coniferous forests. Common. Often mixed with Porella spp. and Radula spp.

F. parvistipula Steph. - 4: the spur of Armovka Mountain, at timberline, on Alnus, 1750 m (Akatova, 19. 06.1999).

F. tamarisci (L.) Dumort. (and.) - 1, 2, 3, 4, 5, 6 (50 $2100 \mathrm{~m}$ ): on the bark of Fagus, Fraxinus, Carpinus, Castanea, Sorbus, Alnus, as well as on regrowth of Abies, sometimes on cliffs in subalpine meadows (K132-1-09). Common. Often mixed with Frullania spp., Porella spp., Radula spp.

* Geocalyx graveolens (Schrad.) Nees (gyn.) - 3: Filmonovskiy Creek, steep slope in deep canyon, AbiesFagus forest with Rhododendron ponticum in understory, on decaying log of Abies, 43 $59^{\prime} 09^{\prime \prime} \mathrm{N}-$ 4009'15' E, 807 m (K458-2-07), with Crossogyna autumnalis, Blepharostoma trichophyllum. 4: right bank of the Urushten River, broad-leaved forest $(\mathrm{Fa}$ gus orientalis dominated with ferns in the ground layer, 435' $53^{\prime \prime} \mathrm{N}$ - 4040'28"E, $818 \mathrm{~m}$ (K118-309), on trunk of Fagus orientalis covered by mosses, on decaying wood, with an admixture of Lophocolea heterophylla.

Gymnocolea inflata (Huds.) Dumort. (per.) - 5: source of the Zakan River, boggy meadow, on spots of bare peat on slope of a pool, $43^{\circ} 43^{\prime} 45^{\prime \prime} \mathrm{N}-40^{\circ} 41^{\prime} 47^{\prime \prime} \mathrm{E}$, $2411 \mathrm{~m}$. In pure mats (K311-1-08) or mixed with Cephalozia bicuspidata, Lophozia ventricosa (K311-10-08).

Gymnomitrion concinnatum (Lightf.) Corda - 5: Yukha Mountain, north facing wet cliffs, in crevices, 434'37" N - 4041’09"E, 2498 m (K324-5,7-08), with Pseudolophozia sudetica; northeast cirque of Yukha Moumtain, rock field on west bank of lake,

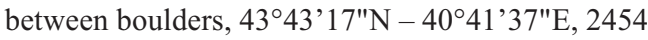
$\mathrm{m}$, with an admixture of Pseudolophozia sudetica, Barbilophozia hatcheri, Diplophyllum taxifolium (K334-1,2,5,8-08).

*Harpanthus scutatus (F.Weber \& D. Mohr) Spruce 3: right bank of the Molchepa River, valley of a small tributary in a deep canyon, Abies-Fagus dominated forest, on moist rotten log of Fagus, 43 ${ }^{\circ} 58^{\prime} 38^{\prime \prime} \mathrm{N}-$ 409'18' E., 849 m (K477-1-07), with Cephalozia bicuspidata, Crossogyna autumnalis; middle reaches of the Filmonovskiy Creek, slope of deep canyon, Abies-Fagus dominated forest with Rhododendron ponticum in the understory, on rotten $\log$ of Abies in Rhododendron stands, 43 $59^{\prime} 22^{\prime}$ 'N 409'40''E, 907 m (K491-5-07), with Cephalozia lunulifolia, Crossogyna autumnalis, Lophocolea heterophylla, Lepidozia reptans.

*Jubula hutchinsiae (Hook.) Dumort. subsp. javani$c a$ (Steph.) Verd. (per.) - 1, 3, 6 (50-1000 m): in deep canyons on shaded moist cliffs near running water, often near waterfalls, sometimes between exposed roots and on soil along trails in Buxus stands. In pure mats or with Metzgeria conjugata, Apometzgeria pubescens, Calypogeia fissa, Plagiochila porelloides, Scapania verrucosa. Sporadic.

*Jungermannia atrovirens Dumort. (per., and., dioicous) $-1,2,3,4,5,6(50-2000 \mathrm{~m})$ : on moist cliffs and rocks on banks of streams mainly in calciumrich sites, on concrete blocks. Often mixed with Leiocolea bantriensis, Pellia endiviifolia, Pedinophyllum interruptum, Scapania cuspiduligera, Scapania verrucosa etc. Sporadic.

*J. eucordifolia Schljakov (per.) - 2, 4, 5 (1500 2500): on rocks in stream-bed and along banks of streams. Usually in extensive pure mats.

**J. pumila With. (per., and., paroicous) - 3: right bank of Belaya River, at the base of cliffs on rocks covered by sandy soil, edge of river bed, $43^{\circ} 58^{\prime} 35^{\prime \prime} \mathrm{N}-$ 406'13' E, 709 m. (K469-5-07), with an admixture of Chiloscyphus pallescens, Jungermannia atrovirens, Pedinophyllum interruptum.

*Leiocolea badensis (Gottsche) Jørg. (per, spor.) - 1, 2, $4(300-2200 \mathrm{~m})$ : on calcium rich cliffs and rocks along streams. Often without an admixture of other hepatics. Frequent.

*L. bantriensis (Hook.) Jørg. - 2, 3, 4 (700 - 2000 m): on detritus, loam, humus on ledges, and in crevices of rocks and cliffs along streams, on peat banks of small streams in subalpine boggy meadows. In pure mats or with Conocephalum conicum, Leiocolea heterocolpos, Schljakovianthus quadrilobus, Plagiochila porelloides, Preissia quadrata. Sporadic. 
*L. collaris (Nees) Schljakov - 2: north facing slope of Oshten Mountain, subalpine meadow, bank of small stream, on soil near water, $44^{\circ} 00^{\prime} 54^{\prime \prime} \mathrm{N}$ 39 57'10"E, 2107 m (K439-3, 7-07), mixed with Chiloscyphus pallescens and Scapania paludosa and boggy subalpine meadow Cirsium-Nardetum stric$t i$, on side of Nardus strictus tufs, $44^{\circ} 00^{\prime} 51^{\prime \prime} \mathrm{N}$ 39॰57’33"E, 2118 m (K442-1-07), with Aneura pinguis.

*L. heterocolpos (Thed. ex Hartm.) H. Buch (gyn., gem.) $-2,3,4,5(700-2200 \mathrm{~m})$ : On peat and humus soil on ledges and in crevices of rocks and cliffs along rivers, on hillocks in boggy subalpine and alpine meadow, on dead lichens and humus at the bottom of cliffs in subalpine meadows. Often with an admixture of Blepharostoma trichophyllum, Cephalozia bicuspidata, Cephalozia pleniceps, Pedinophyllum interruptum, Plagiochila porelloides, Scapania verrucosa. Sporadic.

L. turbinata (Raddi) H.Buch - 6: on wet and shaded basal parts of limestone cliffs (on rocks and lithosoil) in the Khosta River canyon, and the Labirintovaya and Glubokaya Ravines, $43^{\circ} 25^{\prime} \mathrm{N}-39^{\circ} 55^{\prime} \mathrm{E}, 150$ $\mathrm{m}$. Sporadic (Ignatov et al., 2002).

*Lejeunea cavifolia (Ehrh.) Lindb. (per.) - 1, 3, 4, 5, $6(150-1000 \mathrm{~m})$ : on rocks and soil on ledges and in crevices of cliffs in broad-leaved and mixed forests, at the base of limestone cliffs, under overhangs on rocks, on moist schist on the banks of rivers. In pure mats or mixed with Lophocolea heterophylla, Metzgeria furcata, Pedinophyllum interruptum, Plagiochila porelloides, Radula complanata. Frequent.

Lepidozia reptans (L.) Dumort. (per.) - 1, 2, 3, 4, 5, 6 $(150-1700 \mathrm{~m})$ : on rotten logs, rather common in coniferous and broad-leaved-coniferous forests and sporadic in broad-leaved forests. Usually mixed with other epixilous hepatics. Common.

*Liochlaena lanceolata Nees (per., and., spor.) - 2, 3, $5(900-1660 \mathrm{~m})$ : on rotten logs on banks or in beds of streams and on humus in Petasites stand in moist fir or mixed forests along a streams. Sporadic. In pure mats or with an admixture of Crossogyna autumnalis, Blepharostoma trichophyllum, Cephalozia lunulifolia, Geocalyx graveolens, Scapania apiculata.

L. subulata (Evans) Schljak. (per, and., gem., dioicous) - 1, 3, 4 (500 - 900 m): on decaying logs of Abies and Fagus orientalis in deep canyons, often on the banks of streams in broad-leaved and mixed forests, including forests with Rhododendron ponticum in the understory. Usually in extensive pure mats or with an admixture of Blepharostoma trichophyllum. Frequent.

*Lophocolea cuspidata (Nees) Limpr. - 5: valley of Zakan River, near trail in moist coniferous-broad- leaved forest, on bank of stream on rotten log, $43^{\circ} 42^{\prime} 07^{\prime \prime} \mathrm{N}-40^{\circ} 47^{\prime} 08^{\prime \prime} \mathrm{E}, 1312 \mathrm{~m}$ (К305-1-08), mixed with Lophocolea heterophylla, Cephalozia lunulifolia, Calypogeia suecica, Riccardia palmata.

*Lophocolea heterophylla (Schrad.) Dumort. (per., and., spor.) - 1, 2, 3, 4, 5, $6(150-2100 \mathrm{~m})$ : on rotten logs, in coniferous, broad-leaved - coniferous and broad-leaved forests. Mixed with most epixilous hepatics, more often with Blepharostoma trichophyllum, Crossogyna autumnalis, Cephalozia lunulifolia, Lepidozia reptans, Nowellia curvifolia, Riccardia palmata etc. Common.

${ }^{*} L$. minor Nees -3 : right bank of the Belaya River, near the Teplyak River mouth, mossy west facing cliffs, in crevices of cliffs, $43^{\circ} 58^{\prime} 35^{\prime \prime} \mathrm{N}-$ 4006’13"E, $709 \mathrm{~m}$ (K469-8-07, gem.) and right bank of the Belaya River, near Guseripl Town, on

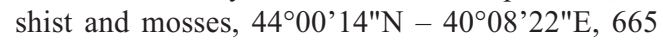
m (K484-1-07, gyn, gem.), mixed with Pedinophyllum interruptum, Plagiochila porelloides.

*Lophozia guttulata A. Evans (per., gem.) - 2, 5 (1400 $-2100 \mathrm{~m}$ ): on decaying logs of Abies and spruce in birch-fir and fir-spruce forests, usually mixed with Blepharostoma trichophyllum, Calypogeia suecica, Cephalozia lunulifolia, Lepidozia reptans, Schistochilopsis incisa and another species of decaying wood.

*L. ventricosa (Dicks.) Dumort. var. longiflora (Nees) Macoun. (per., and., gem.) - 4, 5 (1500 - $2500 \mathrm{~m})$ : on soil among grasses and undershrubs, in tundra, on hillocks in boggy meadow, on peat banks of small streams, on decaying wood in coniferous forests. Usually mixed with Cephalozia bicuspidata, Lophoziopsis excisa, Marsupella funckii or epixilous: Calypogeia suecica, Lepidozia reptans, Lophocolea heterophylla, Riccardia palmata etc. Sporadic.

${ }^{*}$ L. wenzelii (Nees) Steph. var. massularioides Bakalin (gem.) - 4, $5(2100-2400 \mathrm{~m})$ : on soil among herbs in Rhododendron caucasicum - herb community, at the base of hillocks in boggy meadows, sometimes between boulders in rocky streams and on banks of small streams in subalpine meadows. In pure mats or mixed with Barbilophozia lycopodioides, Marsupella funckii. Cephalozia ambigua, Pseudolophozia sudetica. Sporadic. Previously this taxon was known from the Republic of Karachaevo-Cherkessiya only (Ignatova et al., 2008).

var. groenlandica (Nees) Bakalin - 5: north facing slope of the Yukha Mountain spur, on bare soil under rock in a grass-moss-lichen community, 43 $433^{\prime} 9$ " $\mathrm{N}$ 4041'24" E, 2649 m (K340-2-09), some plants with Schistochilopsis opacifolia, Pseudolophozia sudetica.

*Lophoziopsis excisa (Dicks.) Konstant. \& Vilnet (Lo- 
phozia excisa (Dicks.) Dumort.) (per., and., gem.) - $5(2300-2650)$ : slopes of the Yukha Mountain, under rocks and on bare soil among grasses in grasslichen and undershrub-grass-lichen tundra, under overhangs on subvertical soil and rock banks of a dry lake. Mixed with Barbilophozia hatcheri, Cephaloziella divaricata, Scapania brevicaulis, S. praetervisa, Sphenolobus minutus. Sporadic.

*L. longidens (Lindb.) Konstant. \& Vilnet (Lophozia longidens (Lindb.) Macoun) (gem.) - 3: valley of the Molchepa River, deep canyon, on the bark of a large (50-60 sm width) Populus, at a height of $3 \mathrm{~m}$, 435' $49^{\prime \prime} \mathrm{N}-40^{\circ} 10^{\prime} 12^{\prime \prime}$ E, 816 m (K481-1-07, gem.), mixed with Crossogyna autumnalis. 4: north slope of Armovka Mountain, cliffs in moss-grass community, on rock at the bottom of a cliff and in crevices, in the shade of Juniperus sp., $43^{\circ} 52^{\prime} 43^{\prime \prime} \mathrm{N}-$ 40³8'46"E, $2182 \mathrm{~m}$ (K136-1,2,3,4-09), with an admixture of Barbilophozai hatcheri, Ptilidium ciliare.

L. propagulifera (Gottsche) Konstant. \& Vilnet (Lophozia propagulifera (Gottsche) Steph.) (and., gem.) - 5: northeast cirque of Yukha Ridge, north facing rock field on the west bank of a lake, between boulders, on rock covered by humus $43^{\circ} 43^{\prime} 17^{\prime \prime} \mathrm{N}-$ 4041’37"E, 2454 m (K334-7-08).

**Lunularia cruciata (L.) Lindb. (gem.) - 6: right bank of the Khosta River, on loam at the base of limestone cliffs, $43^{\circ} 25^{\prime} \mathrm{N}-39^{\circ} 55^{\prime} \mathrm{E}, 150 \mathrm{~m}$.

**Mannia androgyna (L.) A. Evans - 4: mouth of the Urushten River, left bank, south facing dry cliffs, in

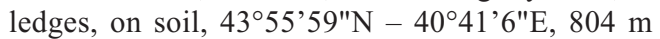
(K105-3-09, K115-3,4-09).

* Mannia fragrans (Balbis) Frye \& L. Clark - 4: mouth of the Urushten River, left bank, south facing dry cliffs, under rock, on mosses, 435 $55^{\prime} 59^{\prime \prime} \mathrm{N}$ 4041'6"E, 804 m (K104-4-09).

*Marchantia polymorpha L. subsp. polymorpha (M. aquatica (Nees) Burgeff) - 2: left bank of the Kurdzhips River, on cliffs near the bed of the river, 444'59'” N - 3959'59'’E, 1495 m (K427-07).

* subsp. montivagans Bischl. \& Boissel.-Dub. (M. alpestris (Nees) Burgeff). (spor.) - 2: north facing slope of Oshten Mountain, boggy subalpine meadow, mossy bank of small stream, on mosses,

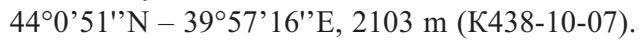

subsp. ruderalis Bischl. \& Boissel.-Dub. (M. latifolia Gray, M. polymorpha auct. non L.) - 1, 2, 3, 6 (50$1600 \mathrm{~m}$ ): on soil and mosses on banks of streams and springs. Sporadic.

Marsupella emarginata (Ehrh.) Dumort. - 1: cliffs along the right bank of the Bushujka Creek, in crevices, 435'29" N - 3950'18" E, 534 m (K400-109).

*M. funckii (F. Weber \& D. Mohr) Dumort. (per.) - 1, $4,5(950-2700 \mathrm{~m})$ : on soil in rocky tundra, in snow bed communities in depressions on slopes, on moist rocks and on spots of bare soil in open Rhododendron caucasicum communities, among rocks on trails. Often in pure mats or with an admixture of Lophozia ventricosa var. longiflora, Calypogeia fissa, Cephalozia bicuspidata, C. pleniceps, Obtusifolium obtusum, etc. Sporadic.

**M. sparsifolia (Lindb.) Dumort. (per., and., paroicous) - 5: source of the Zakan River, under overhangs on subvertical soil and rock banks of a dry lake, 434' $31^{\prime \prime} \mathrm{N}-40^{\circ} 42^{\prime} 30^{\prime \prime} \mathrm{E}, 2318 \mathrm{~m}$ (K310-1,208), mixed with Lophoziopsis excisa and Scapania irrigua.

Metzgeria conjugata Lindb. (gyn., and.) - 1, 2, 3, 4, 5, $6(150-900 \mathrm{~m})$ : on soil, rocks and cliffs along banks of streams, sometimes on bark of broad-leaved trees, in pure mats or with Apometzgeria pubescens, Jubula hutchinsiae subsp. javanica, Plagiochila porelloides. Common.

M. furcata (L.) Dumort. - 1, 2, 3, 4, 5, 6 (150 - 2450 $\mathrm{m})$ : on bark of broad-leaved trees or regrowth of Abies, on rocks and sandy soil on banks of streams. Usually mixed with Frullania spp., Radula spp., Lejeunea cavifolia etc. Common.

Nardia geoscyphus (De Not.) Lindb. (per., and.) - 5: spur of Yukha Ridge, at the bottom of wet north facing cliffs, on rocks, 434' $37^{\prime \prime} \mathrm{N}-40^{\circ} 41^{\prime} 09^{\prime \prime} \mathrm{E}, 2498$ m (K3249-08), mixed with Pseudolophozia sudetica.

*Nowellia curvifolia (Dicks.) Mitt. (per.) - 1, 3, 4, 5, $6(150-900 \mathrm{~m})$ : on rotten logs in broad-leaved and broad-leaved-coniferous forests. In extensive pure mats or mixed with Blepharostoma trichophyllum, Calypogeia suecica, Cephalozia catenulata, Crossogyna autumnalis. Common.

*Obtusifolium obtusum (Lindb.) S.W. Arnell - 4: northeast spur of Armovka Mountain, light birch forest with Rhododendron caucasicum on north facing slope among grasses, 435' $58^{\prime \prime} \mathrm{N}-40^{\circ} 39^{\prime} 39^{\prime \prime} \mathrm{E}$, $1993 \mathrm{~m}$ (K127-1,2-09), in mats with mosses and admixture of Barbilophozia lycopodioides and Plagiochila porelloides. 5: north facing slope of Yukha Mountain, Rhododendron caucasicum - herb community, on moist rock under grasses $43^{\circ} 43^{\prime} 39^{\prime \prime} \mathrm{N}$ 4041'53" E, 2418 m (K320-2-08), with Cephalozia pleniceps, Marsupella funckii.

Odontoschisma denudatum (Mart.) Dumort. (gem.) 6: valley of the Khosta River, „Chertova Vorota“, old beech forest, $43^{\circ} 32^{\prime} 50^{\prime \prime} \mathrm{N}-39^{\circ} 52^{\prime} 30^{\prime \prime} \mathrm{E}$ (Ignatov et al., 2002).

**Pallavicinia lyellii (Hook.) Carruth. (and.) 6:"Chertovy Vorota", old Taxus - Fagus forest, on rotten log of Fagus, 4332'50' N - 39 52'30'”, 119 m (K523-2-07), with Calypogeia fissa, Cephalozia lunulifolia. Previously it was recorded in Caucasus from Georgia by Abramov et al. (1966). 
*Pedinophyllum interruptum (Nees) Kaal. (per., and.) $-1,2,3,4,5,6(150-1600 \mathrm{~m})$ : on wet cliffs, rocks and sandy soil along banks of streams and rivers in deep canyons, on concrete blocks. In extensive pure mats or with Jungermannia atrovirens, Scapania cuspiduligera, S. verrucosa, Plagiochila porelloides, etc. Common in forest zones, in the subalpine zone rather rare.

*Pellia endiviifolia (Dicks.) Dumort. (per.,and.., spor.) $-1,2,3,4,5,6(150-2000 \mathrm{~m})$ : on moist cliffs, rocks and sandy soil on banks of streams and rivers, especially near waterfalls. In pure mats or with Conocephalum spp., Chiloscyphus spp. Common in forest zones, in the subalpine zone rather rare.

*P. neesiana (Gottsche) Limpr. (per., and.) - 4, 5, 6 $(150-2500 \mathrm{~m})$ : on hillocks among Sphagnum, in grass-Sphagnum bogs, on bare soil on banks of pools and on rocks and soil on banks of streams in subalpine meadows, at edges of streams in forests. Frequent.

**Peltolepis quadrata (Saut.) Müll.Frib. (spor.) - 4: north macroslope of mountain at $2589 \mathrm{~m}$, slope of cirque, on moist sandy soil in crevices and under

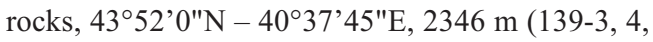
9-09) and in deep crevices and on ledges on very moist calcareous cliffs, $43^{\circ} 51^{\prime} 58^{\prime \prime} \mathrm{N}-40^{\circ} 37^{\prime} 42^{\prime \prime} \mathrm{E}$, 2376 m (K140-1,2-09). Mixed with Athalamia hyalina and Sauteria alpina.

* Plagiochila porelloides (Torrey ex Nees) Lindenb. (and.) - 1, 2, 3, 4, 5, 6 (50-2500): on decaying wood, on roots, on soil in the floor in moist coniferous, broad-leaved and mixed forests, on cliffs and along streams. In extensive pure mats or mixed with hepatics. As an admixture with this species can occur both temperate hepatics (Cololejeunea rossetiana, Metzgeria conjugata, Pedinophyllum interruptum etc.), and northern and montane taxa (Barbilophozia hatcheri, Cephaloziella varians, Scapania brevicaulis, Sphenolobus minutus etc.). Common.

*Plectocolea hyalina (Lyell) Mitt. (per., and., spor.) 2: north slope of Oshten Mountain, subalpine meadow, on soil on boggy bank of stream, $44^{\circ} 00^{\prime} 51^{\prime \prime} \mathrm{N}-$ 39॰57’33"E, 2118 m (K441-4-07), mixed with Cephalozia bicuspidata.

*P. obovata (Nees) Lindb. (per., and.) - 5: Yukha Mountain, north facing moist cliffs, $43^{\circ} 43^{\prime} 37^{\prime \prime} \mathrm{N}-$ $40^{\circ} 41^{\prime} 9^{\prime \prime}$ E, $2498 \mathrm{~m}$. On rock at the bottom of cliffs (K324-1-08), with an admixture of Scapania paludosa or mixed with Anthelia juratzkana, Pseudolophozia sudetica, Scapania subalpina, here in crevices on cliffs, in upper part of cliffs (K324-11-08) mixed with Pseudolophozia sudetica and in wet crevices (K324-2-08) with Scapania subalpina.

P. subelliptica (Lindb. ex Kaal.) A. Evans - 5: northeast cirque of Yukha Ridge, north facing slope, edge of rocky stream, under rock, $43^{\circ} 43^{\prime} 14^{\prime \prime} \mathrm{N}-$ 4041'30"E, 2536 m (K336-1-08).

Porella arboris-vitae (With.) Grolle - 1, 3, 4, 5 (600 $-800 \mathrm{~m}$ ): on boulders and rocks, on exerted roots and fallen trees of Fagus orientalis in broad-leaved (mainly beech) forests, usually in extensive pure mats. Frequent.

P. platyphylla (L.) Pfeiff. - 1, 2, 3, 4, 5, 6 (50 - 1000 $\mathrm{m})$ on exposed roots, bark of broad-leaved trees, on regrowth of Abies, on rocks and sandy soil on banks of rivers and streams. In pure mats or mixed with Frullania dilatata, Metzgeria furcata, Radula lindenbergiana. Common.

*Pseudolophozia sudetica (Nees ex Huebener) Konstant. \& Vilnet (Lophozia sudetica (Nees ex Hobener) Grolle) (gem.) - 4, 5 (2200 - $2500 \mathrm{~m})$ : on rocks covered by soil, between boulders in rock fields, on bare soil among undershrubs and grasses in snow bed communities and tundra, under overhangs on subvertical soil and rock banks of dry lake. Often mixed with Anthelia juratzkana, Barbilophozia hatcheri, Gymnomitrion concinnatum, etc. Sporadic.

Preissia quadrata (Scop.) Nees - 3: right bank of Belaya River, schist cliffs, on ledges and crevices near river bed, 43 $59^{\prime} 27^{\prime \prime} \mathrm{N}-40^{\circ} 7^{\prime} 44^{\prime}$ 'E, $700 \mathrm{~m}$ (K4643, 7, 13-07), with Scapania verrucosa, Plagiochila porelloides, Conocephalum conicum.

*Ptilidium ciliare (L.) Hampe - 4: north slope of Armovka Mountain, cliffs in moss-grass community, on rock in shade of Juniperus sp., 43 $3^{\circ} 52^{\prime} 43^{\prime \prime} \mathrm{N}$ 40³8'46"E, $2182 \mathrm{~m}$ (K136-3-09), among lichens and mosses, with an admixture of Barbilophozia hatcheri, Lophoziopsis longidens. 5: north facing slope of Yukha Mountain spur, on soil in crevice of huge rock 434' $12^{\prime \prime} \mathrm{N}-40^{\circ} 41^{\prime} 44 " \mathrm{E}, 2478 \mathrm{~m}$ (K3421-08).

P. pulcherrimum (Weber) Vain. - 5: northern slopes of Damkhurt Mountain, trail to Luganskiy Pass, AbiesPicea-Fagus forest on bark at the base of Fagus orientalis, $43^{\circ} 42^{\prime} 59^{\prime \prime} \mathrm{N}-40^{\circ} 44^{\prime} 55^{\prime} \mathrm{E}, 1831 \mathrm{~m}$ (K354-4-08), with Radula complanata.

Radula complanata (L.) Dumort. (per., and., spor., gem.) - 1, 2, 3, 4, 5, $6(150-2100 \mathrm{~m})$ : on bark of broad-leaved trees, on regrowth of Abies, on rocks and sandy soil on banks of rivers and streams, under overhangs in crevices and at the bottom of solitary rocks in subalpine meadows. Common.

R. lindenbergiana Gottsche ex C. Hartm. (per., and., spor.) $-1,2,3,4,5,6(150-700 \mathrm{~m})$ : on bark of broad-leaved trees, on leaves and bark of Buxus. Frequent. Often mixed with Frullania spp., Metzgeria furcata, Porella platyphylla.

*Reboulia hemisphaerica (L.) Raddi - 4: cliffs along the left bank of the Urushten River, on ledge under 
grasses, on mosses in beech forest, $4: 43^{\circ} 55^{\prime} 57^{\prime \prime} \mathrm{N}-$ 4040’53"E, 811 m (K111-1a-09).

Riccardia multifida (L.) Gray - 6: on exposed root across wet trail, $43^{\circ} 25^{\prime} \mathrm{N}-39^{\circ} 55^{\prime} \mathrm{E}, 150 \mathrm{~m}$. (Ignatov et al., 2002).

R. palmata (Hedw.) Carruth. (gyn., and., spor.) - 1, 2, $3,4,5$ : on decaying wood in coniferous, moist broadleaved - coniferous, and in broad-leaved forests, not rare in appropriate habitats. Usually mixed with common hepatics of decaying wood: Blepharostoma trichophyllum, Crossogyna autumnalis, Lophocolea heterophylla, Nowellia curvifolia, Calypogeia suecica etc. Frequent.

**Sauteria alpina (Nees) Nees (gyn., and.) - 4: north macroslope of mountain at $2589 \mathrm{~m}$ elevation, slope of cirque, on moist sandy soil in crevices and under rocks, $43^{\circ} 52^{\prime} 0 " \mathrm{~N}-40^{\circ} 37^{\prime} 45^{\prime \prime} \mathrm{E}, 2346 \mathrm{~m}$ (139 - 4, 9-09) and in deep crevices and on ledges on very moist calcareous cliffs, $43^{\circ} 51^{\prime} 58^{\prime \prime} \mathrm{N}-40^{\circ} 37^{\prime} 42^{\prime \prime} \mathrm{E}$, $2376 \mathrm{~m}$ (K140-2,3,5-09), with an admixture of Athalamia hyalina and Peltolepis quadrata.

Scapania aequiloba (Schwägr.) Dumort. (per., and., gem.) - 1, 2, 3, $4(400-2400 \mathrm{~m})$ : on soil under rocks and on bare soil among herbs in subalpine and alpine meadows, on banks of streams in subalpine and forest zone. Usually in pure turfs or with Jungermannia atrovirens, Leiocolea bantriensis, Plagiochila porelloides, Scapania cuspiduligera. Sporadic.

S. apiculata Spruce (gem.) - 5: northern slopes of Damkhurt Mountain, trail to Luganskiy Pass, moist rotten $\log$ in the bed of a stream, on hardwood,

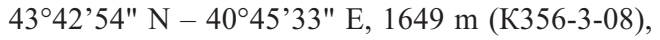
some plants at the edge of mats with a mixture of Liochlaena lanceolata, Lophocolea heterophylla, Cephalozia lunulifolia.

${ }^{*} S$. aspera M.Bernet \& Bernet (per., spor.) - 4: north macroslope of mountain at $2589 \mathrm{~m}$ elevation, steep slope of cirque, under overhang, by undershrubs, wet ledge of rock, $43^{\circ} 51^{\prime} 55^{\prime \prime} \mathrm{N}-40^{\circ} 37^{\prime} 50^{\prime \prime} \mathrm{E}, 2453$ m (K141-6a-09).

${ }^{* * S}$. brevicaulis Taylor (gem.) - 5: steep west facing slope in cirque of Yukha Ridge, grass-undershrub lichen communiy, on soil under small rocks and undershrubs, $43^{\circ} 43^{\prime} 35^{\prime \prime} \mathrm{N}-40^{\circ} 41^{\prime} 01$ "E, $2521 \mathrm{~m}$ (K330-1,3,2,4-08), mixed with Lophoziopsis excisa, Cephaloziella divaricata, Plagiochila porelloides, Sphenolobus minutus, Scapania praetervisa.

* S. carinthiaca J.B. Jack ex Lindb. (gem.) - 3: deep canyon in the middle of Molchepa River, on moist occasionally submerged rotten log, 43 $57^{\prime} 49^{\prime \prime} \mathrm{N}-$ 40¹0'12' E, 816 m (K480-3-07, K482-1-07), with Nowellia curvifolia, Blepharostoma trichophyllum, Lophocolea heterophylla, Riccardia palmata.

* S. cuspiduligera (Nees) Müll.Frib. (per., gem.) - 2: right bank of Kurdhzips River, on rotten log cov-

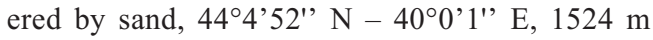
(K423a-07). 3: right bank of the Belaya River, schist cliffs, on ledges and crevices near river bed, 4359'27' ' N-407'44'” E, 700 m (K464-в, 17, 19, 2007), with an admixture of Scapania verrucosa, Preissia quadrata, Pedinophyllum interruptum, Jungermannia atrovirens.

*S. helvetica Gottsche - 2: north-east slope of Abadzesh Mountain (upper Kurdzhis River Basin), subalpine Alchemilla-grass meadow under gletcher, on bare soil, 44³'42' N - 3958'34' E, 1989 m (K414-107, gem.).

* S. irrigua (Nees) Nees (and., gem.) - 2, 4, 5 (2100 $2500 \mathrm{~m}$ ): on peat, soil and rocks covered by soil, on the side of hillocks on banks of small streams and pools in boggy meadow and herb-sedge-Sphagnum bogs. Often mixed with Scapania spp., Pellia neesiana, Cephalozia bicuspidata etc. Sporadic.

S. nemorea (L.) Grolle (gem.) - $1(400-800 \mathrm{~m})$ : on sandy soil along road and trails in broad-leaved (chestnut, chestnut-beech and beech) forests, on cliffs, rocks and sometimes on rotten logs on banks of streams, in pure turfs or mixed with Calypogeia fissa, Diplophyllum albicans, Jubula hutchinsiae subsp. javanica, Metzgeria conjugata. Sporadic.

*S. paludosa (Müll. Frib.) Müll. Frib. - 2, 4, 5 (2100 $-2500 \mathrm{~m}$ ): on soil among herbs in boggy meadow and herb-sedge-Sphagnum bogs, on soil and rocks on edges of brooks and pools in the subalpine zone. In pure mats or mixed with Scapania irrigua, $S$. subalpina, Pellia neesiana, Cephalozia pleniceps, C. bicuspidata, Calypogeia muelleriana. Sporadic. *S. praetervisa Meyl. - 5: steep west facing slope in the cirque of Yukha Ridge, on soil under small rocks and undershrubs in herbaceous-undershrub lichen community, 434' $35^{\prime \prime} \mathrm{N}-40^{\circ} 41^{\prime} 01^{\prime \prime E}, 2521 \mathrm{~m}$ (K330-1, 2,3-08), with Sphenolobus minutus, Scapania brevicaulis, Lophoziopsis excisa, Cephaloziella divaricata, Plagiochila porelloides.

S. scandica (Arnell \& H.Buch) Macvicar - 1: floodplain forest on right bank of the Shakhe River, on

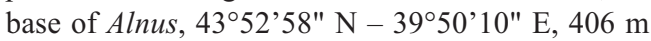
(K393-1-08).

S. subalpina (Nees ex Lindenb.) Dumort. - 5: Source of Zakan River, boggy meadow, on hillocks on bank of stream, on soil, 434' $55^{\prime \prime} \mathrm{N}-40^{\circ} 41^{\prime} 36^{\prime \prime}$ E, 2425 $\mathrm{m}(\mathrm{K} 318-4 \mathrm{~b}-08)$; here on rocks in the bed of stream, 434' 45" N - 4041'47" E, 2411 m (K311-2-08) and at the bottom of rocks (K311-8-08).

S. umbrosa (Schrad.) Dumort. (per., gem.) - 5: northern slopes of Damkhurt Mountain, trail to Luganskiy Pass, broad-leaved - coniferous forest, on moist rotten log of Abies on bank of stream, $43^{\circ} 42^{\prime} 54^{\prime \prime} \mathrm{N}$ - 404’33" E, 1649 m (K357-2,3,4-08), several 
plants with Schistochilopsis incisa, Calypogeia suecica, Lepidozia reptans, Tritomaria execta, Blepharostoma trichophyllum, Lophocolea heterophylla, Lophozia ventricosa var. guttulata, Cephalozia lunulifolia.

* S. undulata (L.) Dumort. (per., and., gem.) - 1, 3, 4, $5(400-2500 \mathrm{~m})$ : on rocks and cliffs, sometimes on logs on banks of streams near or in running water. In pure turfs or with an admixture of Jungermannia atrovirens, Scapania verrucosa, Plagiochila porelloides etc. Sporadic.

* S. verrucosa Heeg. (gem.) - 1, 3, 4 (500 - 850 m ): in crevices on moist cliffs on banks of streams, often mixed with Scapania cuspiduligera, Pedinophyllum interruptum, Jungermannia atrovirens, Plagiochila porelloides, Conocephalum spp. Sometimes on decaying logs in running water with $\mathrm{Baz}$ zania tricrenata, Tritomaria exsecta. Sporadic.

* Schistochilopsis incisa (Schrad.) Konstant. (per., spor.). - 3, 4, 5 (1500-1900 m): on moist decaying wood of fir and spruce in broad-leaved -coniferous and in coniferous forest. Usually with other mainly epixilous species: Tritomaria exsecta, Blepharostoma trichophyllum, Calypogeia suecica, Cephalozia lunulifolia, Lepidozia reptans etc. Sporadic.

*S. opacifolia (Culm. ex Meyl.) Konstant. - 2: boggy meadow, on hillock, 440'51' N $-39^{\circ} 57^{\prime} 33^{\prime \prime}$ E, 2118 m (K442-6c-07), some plants among Cephalozia pleniceps, C. bicuspidata, Blepharostoma trichophyllum, Leiocolea heterocolpos, Scapania irrigua, Solenostoma confertissimum. 4: north slope of Armovka Mountain, on bare soil on slope to the trail in Rhododendron caucasicum stands, $43^{\circ} 52^{\prime} 42^{\prime \prime} \mathrm{N}$ - 40³8’39"E, 2185 m (K138-1-09) 5: north facing slope of Yukha Mountain spur, on bare soil under rock in grass-moss-lichen community, $43^{\circ} 43^{\prime} 9{ }^{\prime \prime} \mathrm{N}$ - 4041'24" E, 2649 m (K340-2-09), some stems with Lophozia wenzelii var. groenlandica, Pseudolophozia sudetica.

*Schljakovianthus quadrilobus (Lindb.) Konstant. \& Vilnet (Orthocaulis quadrilobus (Lindb.) H.Buch.) - 2: north facing slope of Oshten Mountain, boggy meadow, on side of hillocks, $44^{\circ} 00^{\prime} 51^{\prime \prime} \mathrm{N}$ 39॰57’33'”E, $2118 \mathrm{~m}$ (K442-5,6,-07); north facing cliffs near Asishskiy Pass, on dead lichens in grassy community at the bottom of cliffs, $44^{\circ} 5^{\prime} 6^{\prime \prime} \mathrm{N}-$ $40^{\circ} 0^{\prime} 47^{\prime}$ 'E, $1719 \mathrm{~m}$ (K443-3-07), with Leiocolea heterocolpos.

* Solenostoma confertissimum (Nees) Schljakov (per., and.) - 2: north facing slope of Oshten Mountain, subalpine meadow, on soil on bank of brook, 440'54" N - 3957'10" E, 2107 m (K439-4, per., and.).

* Solenostoma gracillimum (Sm.) R.M. Schust. (per.) - 1: southern spur of Khuko Mountain, on edge of trail to Cherkesskiy Pass, $43^{\circ} 54^{\prime} 02^{\prime \prime} \mathrm{N}-39^{\circ} 49^{\prime} 51^{\prime \prime}$ E, 779 m (K378-1-08), with Calypogeia fissa and on the edge of the same trail, $43^{\circ} 54^{\prime} 011^{\prime \prime} \mathrm{N}-$ 3949'56" E, 800 m (K373-1-08); 2: on loam among herbs, on side of doline (deep hole-like karst depression on gentle slope), $44^{\circ} 4^{\prime} 37^{\prime \prime} \mathrm{N}-39^{\circ} 59^{\prime} 54^{\prime \prime}$ E, $1589 \mathrm{~m}$ (K412-07).

* Solenostoma sphaerocarpum (Hook.) Steph. - 5: north facing cliffs among alpine meadow on the Yukha Ridge spur, in crevice, 43.43'37"N 4041’09"E, $2498 \mathrm{~m}$ with Pseudolophozia sudetica (K324-4-08), here in another cliffs with Diplophyllum taxifolium $($ K327 3 - 08$)$ and on steep slope at the bottom of rock, $43^{\circ} 43^{\prime} 09^{\prime \prime} \mathrm{N}-40^{\circ} 41^{\prime} 24^{\prime \prime} \mathrm{E}, 2650$ m (K340-3-08), with Anthelia juratzkana.

Southbya tophacea (Spruce) Spruce - 1: right bank of the Shakhe River, on moist cliffs on the side of a road 4351'59" N - 3946’31" E, $258 \mathrm{~m}$ (K422-308). 6: on wet and shaded basal parts of limestone cliffs, $43^{\circ} 25^{\prime} \mathrm{N}-39^{\circ} 55^{\prime} \mathrm{E}, 150 \mathrm{~m}$. (Ignatov et al., 2002).

*Sphenolobus minutus (Schreb.) Berggr. (per., gem.) -5 : steep west-facing slope in the cirque of Yukha Ridge, grass-undershrub-lichen community, on bare soil under small rocks and among undershrubs,

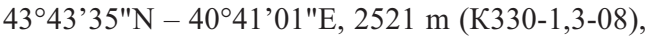
with Scapania brevicaulis, Lophoziopsis excisa, Cephaloziella divaricata, Plagiochila porelloides

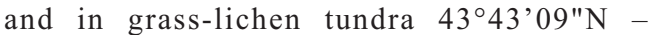
4041'24"E, 2649 m (K339-1c-08), with Cephalozia pleniceps; north facing slope of Yukha Mountain, in the crevice of a huge rock $43^{\circ} 43^{\prime} 12^{\prime \prime} \mathrm{N}-$ 4041'44"E, $2478 \mathrm{~m}$ (K342-2-08).

*Tritomaria exsecta (Schmidel) Schiffn. ex Loeske (per., gem.) - 2, 3, 4, 5 (600-1800 m): on decaying wood in fresh coniferous (Abies, Picea) and broadleaved - coniferous forests, usually mixed with Blepharostoma trichophyllum, Lepidozia reptans, Schistochilopsis incisa. Frequent.

* Tritomaria quinquedendata (Huds.) H. Buch (per.) $-2,3,4,5(1700-2500 \mathrm{~m})$ : alpine and subalpine zones, on the sides of hillocks in boggy meadows, in crevices on cliffs and rocks in subalpine meadows, on dead lichens at the bottom of cliffs in mixed forest near timberline. Usually in pure mats, sometimes with an admixture of Barbilophozia hatcheri, Leiocolea heterocolpos. Sporadic.

\section{DISCUSSION}

The list of hepatics of the CSNR includes 126 species (130 taxa) that represent ca. 69\% of species known from the Caucasus. Among them, 12 are new for the Russian part of the Caucasus, 77represent new records for the Republic of Adygeya. Nine of those that are new for the Cau- 
casus (Cephalozia ambigua, Cephaloziella aspericaulis, C.varians, Calypogeia sphagnicola, Jungermannia pumila, Marsupella sparsifolia, Peltolepis quadrata, Sauteria alpina, Scapania brevicaulis) are arctomontane species. Apart from Cephaloziella aspericaulis and Marsupella sparsifolia, which have restricted distributions, all of these species are more-or-less widespread circumpolar hepatics. All of them were collected above $2300 \mathrm{~m}$. The most interesting discovery was Cephaloziella aspericaulis. It is known from single localities in Norway and Greenland (Damsholt, 2002) and several localities in Russia, in particular from the Siberian Arctic and South Siberia (Konstantinova, Bakalin et al., 2009). Undoubtedly, this very small species is under recorded. Two species that are new for the Russian part of the Caucasus (Lunularia cruciata, Pallavicinia lyellii) were found in the coastal area of the Black Sea, particularly in the valley of the Khosta River. These taxa are known from coastal areas of Georgia (Abramov et al., 1966, Duda, 1982), so finding them in coastal areas of the Krasnodarskiy Territory was predictable. Mannia androgyna was recorded early from "Osetia, Lars et Kobi ad fl. Terek” (Brotherus, 1892). It is hard to calculate if this part of Osetia belongs to Russia or not. Our report of this species from CSNR is the first exact findings of Mannia androgyna in Russia and Caucasus particularly. One species Calypogeia sphagnicola is characteristic species of Sphagnum bogs that are very rare in Caucasus.

The hepatic flora of the Republic of Adygeya has never been studied stable. Only 26 hepatic species were reported for this Republic earlier (Akatova \& Otte, 2007), so it is not surprising that numerous novelties are recorded in the present study. Among the new records, the majority of species are widespread temperate, boreal, montane and arctoboreomontane species. Additionally, a number of rare species were collected, including most of those that are new for the Caucasus (noted above) and several Caucasus novelties recently recorded for the Teberdinskyi State Nature Reserve TSNR (see below), in particular, Calypogeia azurea, Gymnocolea inflata, Obtusifolium obtusum, Scapania carinthiaca, as well as a number of red-listed European species (see below).
COMPARISON HEPATIC FLORA OF CSNR AND OF THE TEBERDINSKYI STATE NATURE RESERVE (TSNR)

The species list presented herein represents the first step in the study of the hepatics of the CSNR, and further investigations are needed. We studied just a small area of this huge reserve (Fig.1) and did not cover all the diversity of hepatic habitats present in the CSNR. Nevertheless, the present number of species of the CSNR is higher than that recorded for the much better studied Teberdinskyi State Nature Reserve (TSNR) (Ignatova et al., 2008) (126 versus 110 for the TSNR). The last one is located quite close to CSNR and have comparable diversity of physical features and habitats. Comparison of the hepatic floras of the two reserves shows that they have 86 taxa in common. Twenty-four hepatics present in the TSNR have not been found in the CSNR. Most of these species are arctic-montane (Asterella gracilis (F.Weber) Underw., Cephaloziella grimsulana (J.B.Jack ex Gottsche \& Rabenh.) Lacout., Gymnomitrion brevissimum (Schleich. ex Dumort.) Warnst., G. corallioides Nees, Isopaches decolorans (Limpr.) H.Buch, Jungermannia borealis Damsh. \& Váňa, Scapania gymnostomophila Kaal., Pseudolophozia debiliformis (R.M.Schust. \& Damsh.) Konstant. \& Vilnet), montane (Eremonotus myriocarpus (Carrington) Pearson, Lophozia lantratoviae Bakalin, Marsupella aquatica (Lindenb.) Schiffn., M. sphacelata (Gieseke ex Lindenb.) Dumort., Porella cordaeana (Huebener) Moore, Scapania lingulata H.Buch) or arctoboreomontane (Isopaches bicrenatus (Schmidel ex Hoffm.) H.Buch). All were found in the TSNR at higher elevations (above $1800 \mathrm{~m}$ ). Alpine vegetation in the Caucasus does not form a continuous belt. Plots with alpine vegetation are dispersed at higher elevations and represent more-or-less small "islands" on steep slopes. The diversity of hepatics in such "islands" is usually quite low and differs from one site to another. As a result, the distributions of many arctic-montane species are disjunctive and restricted to limited areas, so great efforts must be made to study many sites to reveal the diversity of hepatics in the alpine zone. Undoubtedly, more detailed future studies at high elevations in the CSNR will add to the species diversity of the reserve. 
A relatively large group of hepatics that have been recorded for the TSNR, but not yet in the CSNR include relatively rare mostly epixilic hepatics of coniferous or mixed forests (Calypogeia integristipula Steph., Crossocalyx hellerianus (Nees ex Lindenb.) Meyl., Lophozia ascendens (Warnst.) R.M.Schust., L. ciliata Damsh. et al., L. silvicola H.Buch, Orthocaulis attenuatus (Mart.) A.Evans, Tritomaria exsectiformis (Breidl.) Loeske, etc.). Some of them were recently discovered in the Caucasus, and the rest are relatively rare in the Caucasus. We studied only very small plots of coniferous and mixed forests in the CSNR, which is the main reason that a number of epixilous hepatics are absent from our collections. Undoubtedly, all of these species will be collected in the CSNR in the future.

Two wetland hepatics (Cladopodiella fluitans (Nees) H.Buch and Riccardia chamaedryfolia (With.) Grolle) that are known in the Caucasus only from the TSNR were restricted to relatively high elevations and without doubt shall be found in the CSNR in future detailed studies.

Among 39 species collected in the CSNR and not recorded for the TSNR, the majority are temperate and subtropical temperate species restricted to coastal areas and the southern slopes of the Caucasus. It is unlikely that some of them were under-collected in the TSNR because there are no appropriate habitats for them in this reserve, the lowest elevation of which is $1280 \mathrm{~m}$. Also, 12 species are obligate calciphiles, and in the Teberda River basin where the TSNR is situated, limestone rocks are absent, which resulted in reduced numbers of calciphiles.

\section{CONSERVATION VALUE OF THE HEPATIC FLORA OF THE CSNR RESERVE}

Among the hepatics collected in the CSNR, eight species are red-listed in Europe. Two of them, Frullania parvistipula, Scapania carinthi$a c a$, are endangered in Europe, two (Frullania bolanderi and Pallavicinia lyellii) are vulnerable, three (Jubula hutchinsiaae subsp. javanica, Liochlaena subulata, Scapania verrucosa) are rare, and one (Scapania brevicaulis) has unknown status (Schumacker \& Matriny, 1995). Apart from these, five (Cephaloziella turneri, Cololejeunea calcarea, Cololejeunea rossetiana, Leiocolea turbinata, Southbya tophacea) are additionally red-listed for the Krasnodar Territory (Konstantinova, 2007).

Both species that are endangered in Europe, as well as Pallavicinia lyellii and Scapania brevicaulis, are known from single localities. Most of the other red-listed species were relatively frequent For example, three taxa, Jubula hutchinsiaae subsp. javanica, Liochlaena subulata, Scapania verrucosa, were collected in many localities in several parts of the CSNR and can be locally fairly abundant. Thus, the CSNR represents a significant area for conservation of those species.

The discovery of hepatic species previously unreported for the Caucasus and some of its regions, as well as new findings of rare and very rare species, demonstrate the need for greater research in the Caucasus, particularly in the upper mountains and coniferous forests. Certainly, many species are more common than they appear in the present list. This is especially true for some that are rare and recently discovered in the Caucasus.

\section{ACKNOWLEDGMENTS}

The administration of the Caucasian State Nature Reserves and Dr. V. Akatov are thanked for their comprehensive assistance with the organization of the field trip. Thanks are also to D. Horton for improving the English of the manuscript and valuable comments. The work was supported by the Russian Foundation for Basic Researche, grant numbers 09-04-00281, 07-0410152, and 08-04-10098.

\section{LITERATURE CITED}

[ALISOV, В.Р.] АЛИСОВ Б.П. 1956. Климат СССР. - [Klimat SSSR] Л.: Наука [Moscow, Moscow, State Universit]: 28-30, 103-110.

[AKATOVA, T.V.] АКАТОВА Т.В. 2002. Листостебельные мхи Кавказского заповедника (Западный Кавказ, Россия) - [Moss flora of the Caucasian Nature Reserve (Western Caucasus, Russia)] Arctoa 11: 179-204.

AKATOVA, T.V. \& V. OTTE 2007. Bryophytes of the Nature Park "Bol'shoj Thach and adjacent territories. - Abh. Ber. Naturkundemus. Gurlitz. 79 (1): 115-130.

[ABRAMOV, I.I., A.L.ABRAMOVA \& J. DUDA] АБРАМОВА А.Л., И.И. АБРАМОВ, Й. ДУДА 1966. К флоре печеночных мхов Кавказа (Аджария). - [On hepatic flora of Caucasus (Adzharia)] Новости сист. низи. pacm. [Novosti Sist. Nizsh. Rast.] [1966 '3']: 287-297.

BROTHERUS, V.F. 1892. Enumeratio muscorum Caucasi. Hepaticae. - Acta Soc. Sci. Fenn. 19(12): 141-161. 
CHUBUKOV, L.A. 1966 Л.А. Кавказ. - [Caucasus] Климат [Klimat] M., Наука [M.: Nauka]: 85-126.

DAMSHOLT, K. 2002. Illustrated flora of Nordic liverworts and hornworts. - Nord. Bryol. Soc., Lund, 840 pp.

[DUDA, J.] ДУДА Й. 1982. К распространению печеночных мхов на Кавказе. - [On distribution of hepatics in Caucasus] Новости сист. низи. pacm. [Novosti Sist. Nizsh. Rast.] 19: 200-204.

[DUDA, J.] ДУДА Й. 1988. Zwei Lebermoose - Lophozia turbinata und Sphenolobopsis kitagawae neu für die Sowjetunion. - Preslia 60: 115-119.

[DUDA, J. \& A. VEZDA] ДУДА Й., А. ВЕЗДА 1981. Lejeunea patens Lindb. - новый вид для Кавказа. - [Lejeunea patens Lindb., a new species for Caucasus] Новости сист. низи. pacm [Novosti Sist. Nizsh. Rast.] 18: 207-208.

IGNATOV, M. S., E. A. IGNATOVA, T. V. AKATOVA \& N. A. KONSTANTINOVA 2002. Bryophytes of the Khosta' Taxus and Buxus Forest (Western Caucasus, Russia). - Arctoa 11: $205-214$.
[IGNATOVA, E.A., M.S. IGNATOV, N.A.KONSTANTINOVA, V.I. ZOLOTOV \& V.G. ONIPCHENKO] ИГHАТОВА Е.A., М.С. ИГНАТОВ, Н.А. КОНСТАНТИНОВА, В.И. ЗОЛОТОВ, В.Г. ОНИПЧЕНКО 2008. Флора мохообразных Тебердинского заповедника. [Bryophytes of the Teberdinskiy State Nature Reserve] Флора и фауна заповедников [Flora i fauna zapovednikov] 112: $1-86$.

[KONSTANTINOVA, N.A.] КОНСТАНТИНОВА Н.А. 2007. Печеночники. - [Liverworts] В кн.: Красная книга Краснодарского края. (Растения и грибы). Краснодар. [In: Red Data Book of Krasnodar Territory (Plants and Funguses), Krasnodar]: 290-295, 450-453.

KONSTANTINOVA, N.A., V.A. BAKALIN et al. 2009. Checklist of liverworts (Marchaniophyta) of Russia [Список печеночников (Marchaniophyta) России]. - Arctoa 18: 1-63.

SCHUMACKER, R. \& PH. MATRINY 1995. Threathened bryophytes in Europe in Macaronesia. - E.C.C.B. (ed.) Red Data book of European bryophytes. Part. 2. Trondheim: 29-193. 